Article

\title{
Key Barriers of Digital Transformation of the High-Technology Manufacturing: An Evaluation Method
}

\author{
Alexey Borovkov ${ }^{1}$, Oleg Rozhdestvenskiy ${ }^{1}$, Elizaveta Pavlova ${ }^{1, *}$, Alexey Glazunov ${ }^{2}$ and Konstantin Savichev ${ }^{3}$ \\ 1 The World-Class Research Center "Advanced Digital Technologies", Peter the Great St. Petersburg \\ Polytechnic University, 195251 Saint Petersburg, Russia; borovkov@spbstu.ru (A.B.); \\ olegrojd@spbstu.ru (O.R.) \\ 2 Research and Production Association "Centrotech", 624130 Novouralsk, Russia; AIgGlazunov@rosatom.ru \\ 3 Joint Stock Company "Power Machines-ZTL, LMZ, Electrosila, Energomachexport" (JSC "Power Machines"), \\ 195009 Saint Petersburg, Russia; Savichev_KD@power-m.ru \\ * Correspondence: pavlova_ei@spbstu.ru; Tel.: +7-812-775-05-20
}

Citation: Borovkov, A.;

Rozhdestvenskiy, O.; Pavlova, E.;

Glazunov, A.; Savichev, K. Key

Barriers of Digital Transformation of the High-Technology Manufacturing: An Evaluation Method. Sustainability 2021, 13, 11153. https://doi.org/ $10.3390 /$ su132011153

Academic Editor: Yury Klochkov

Received: 11 August 2021

Accepted: 24 September 2021

Published: 9 October 2021

Publisher's Note: MDPI stays neutral with regard to jurisdictional claims in published maps and institutional affiliations.

Copyright: (c) 2021 by the authors. Licensee MDPI, Basel, Switzerland. This article is an open access article distributed under the terms and conditions of the Creative Commons Attribution (CC BY) license (https:/ / creativecommons.org/licenses/by/ $4.0 /)$.

\begin{abstract}
It is acknowledged that quality of life is related to economic development in a country or region. The impact of the ongoing transfer to the digital economy on economic growth, sustainable development, and quality of life has been a recent academic focus, finding that the development of digitalisation of the economy and society is happening at a comparable pace. Yet, despite the availability of governmental support and overall strategic orientation of top managers, there is evidence of low digital/advanced manufacturing technologies adoption readiness across economic sectors. Therefore, the object of the research is the digital/advanced manufacturing technologies adoption readiness, which can be assessed on both industrial and organisational levels. The authors carried out an expert poll that has shown low digital/advanced manufacturing technologies adoption readiness on the industrial level (average readiness of 2.18 across estimated industries). For this reason, the focus subject of the research is the evaluation method for determining barriers of digital transformation on organisational level. The review of the academic literature and available digital maturity assessment models has shown the lack of metrics for barrier evaluation. The objective of the research is to develop a method for digital-transformation barrier evaluation. An analytical research method is used to develop a ready-to-use method in a form of a questionnaire that can be applied to measure an overall digital-transformation barrier level and identify problem areas for a manufacturing enterprise. The developed method is approbated in two large industrial companies. The overall barrier equals $39.3 \%$ for a power engineering company, which is a deterrent barrier. The overall barrier equals $75.0 \%$ for a machine-building company, which is a limiting barrier. The results of approbation correspond with results of the expert poll: the power engineering company has a lower barrier level, which is in line with the engine building and turbine engineering industry showing higher levels of readiness to adopt digital technologies. This finding supports the hypothesis about the rationality of the author's method.
\end{abstract}

Keywords: quality of life; digitization; digital transformation; business strategy; processes operations; digital maturity assessment

\section{Introduction}

\subsection{Research Background}

It is acknowledged that quality of life is related to economic development in a country, region, etc. Various studies measure the quality of life using Gross Domestic Product (GDP) or introduce new indicators [1]. The influence of economic development on the standard of living of citizens was considered in [2]. The relations between the GDP energy intensity and the quality of life were studied in [3].

The impact of the ongoing transfer to the digital economy on economic growth and quality of life has been a recent academic focus. The specific features of the digital and cyber 
economy influence human living standards, evaluate the current changes in human living standards under the influence of technological transformation, and outline the conditions under which the changes will have the most positive outcomes for quality of life [4]. Digital transformation of the manufacturing sector and services, healthcare and education, and financial sector and other economic sectors is followed by positive developments in quality of life [5]. Mobile applications help the population solve issues of sharing knowledge and experience and information, purchasing and selling goods, facilitating communication between people regardless of their location, providing an opportunity to pay for housing and communal services as well as fines and taxes with minimum time, and speeding up the process of solving the population's transportation problems [6]. In [7], the authors offered a schematic diagram of data collecting and processing in the start-to-finish automated production-and-marketing chain of activity within the agricultural sector. The achievement of these goals will allow increasing the agricultural sector contribution into Russian economy to boost export revenue and to schedule and aggregate data streams for creation of start-to-finish chains and technologies from the agricultural production stage to consumption, with a deep integration into allied industries of the digital economy. The positive impact of digitalisation is identified for economically developed and rich regions. In contrast, for less developed regions, this impact could entail digital risks [8]. All in all, the authors conclude that the development of digitalisation of the economy and society is happening at a comparable pace [9].

Digital technologies are one of the key trends of sustainable and innovative development [10], having a strong and often disruptive impact on business strategies and business models [11]. The essence of a business model is in defining how the enterprise delivers value to customers, entices customers to pay for value, and converts those payments to profit [12]. Digital technologies tend to be a key element that ensures the global competitiveness of modern products and services [13]. The importance of digital technologies development and diffusion is stated in national strategic plans for innovative and sustainable development [14]. Key administrative and legislative barriers that exist on the governmental level are also recognized. Roadmaps for overcoming such barriers are being developed and implemented. However, despite the availability of governmental support and overall strategic orientation of top managers, there is evidence of low digital/advanced manufacturing technologies adoption readiness across economic sectors, which is further looked into in the present research.

\subsection{Literature Review}

On the organizational level, the introduction of digital technologies is divided into three stages: digitization, digitalisation, and digital transformation [15]. Various strategies and business models that manufacturing enterprises pursue in digital transformation were discussed in [16]. Reaching each stage successfully requires specific organizational structure, growth and transformation strategy formulation, certain assets, and human resources in SMEs and large corporations [17,18].

It is acknowledged that an important part of digital transformation lies in tackling the barriers $[19,20]$. In order to tackle the barriers, which arise when adopting digital technologies, the first step is to identify them within the firm. In [21], the study aimed at identifying the general barriers on the basis of 46 expert interviews. Key identified barriers include missing skills, technical barriers, individual barriers, organizational and cultural barriers, and environmental barriers. Yet, the authors did not touch the subject of barrier measurement while developing agenda for further research. In [22], such barrier groups were identified as systems and technologies, processes, people and competence, culture, and strategy. In the article [23], corresponding barrier groups were discussed (technological, financial, organizational, governmental, psychological, and process barriers) while adding a new barrier, which is a financial barrier. The importance of this barrier was highlighted in [19] since it is proved that greater perceived economic and financial barriers do not induce firms to adopt more incentives. In [24], the authors focused on the 
discussion of the barriers to digital transformation before, during, and what may continue after the COVID-19 pandemic. Both [24,25] offered a new strategy discipline to overcome barriers but left the barrier assessment task out-of-loop.

The transformation journey and its status are generally measured using specific metrics aggregated into the digital maturity assessment model. Many maturity models have been developed over the last years, both by practitioners and research [26]. A vast review of existing models is available in which 18 models were identified and evaluated concerning their validity of measurement [27]. The authors focused on reviewing assessable digital maturity models from prior research as well as identifying models that have not been studied previously. The authors' review is structured into the source, scope, and barrier evaluation metrics analysis (whether the tools to elicit barriers (1) are represented, (2) allow direct or indirect evaluation, (3) or are not represented). The review took a qualitative approach to available models. In Table 1 , the available digital maturity assessment models are listed. The authors identified 18 models with different scopes and authorship. The models were reviewed in terms of barrier evaluation metrics availability.

Table 1. Authors' review of the available digital maturity assessment models.

\begin{tabular}{|c|c|c|c|c|}
\hline № & Model & Source & Scope & Barrier Evaluation Metrics \\
\hline 1 & $\begin{array}{l}\text { The Industry } \\
\text { 4.0/Digital Operations } \\
\text { Self-Assessment [28] }\end{array}$ & PWC & Industrial products companies & Not represented \\
\hline 2 & $\begin{array}{l}\text { Digital Maturity } \\
\text { Model [29] }\end{array}$ & InfoCert. & $\begin{array}{l}5 \text { business capability dimensions for industrial } \\
\text { products companies }\end{array}$ & Not represented \\
\hline 3 & $\begin{array}{l}\text { Digital Maturity } \\
\text { Assessment [30] }\end{array}$ & Avanade & Customer experience & Not represented \\
\hline 4 & $\begin{array}{l}\text { BCG's Digital Acceleration } \\
\text { Index [31] }\end{array}$ & BCG & $\begin{array}{l}\text { Digital maturity in } 36 \text { categories, such as } \\
\text { customer journeys, digital supply chain, } \\
\text { marketing personalization }\end{array}$ & Not represented \\
\hline 5 & $\begin{array}{c}\text { Digital Maturity } \\
\text { Assessment Tool [32] }\end{array}$ & $\begin{array}{l}\text { Government of } \\
\text { South Australia }\end{array}$ & $\begin{array}{l}\text { Governance and leadership, People and culture, } \\
\text { Capacity and capability, Innovation, Technology }\end{array}$ & Not represented \\
\hline 6 & $\begin{array}{l}\text { Digital Maturity } \\
\text { Model [33] }\end{array}$ & Deloitte & $\begin{array}{c}\text { Evaluation for organization across dimensions: } \\
\text { customer, strategy, technology, operations, } \\
\text { organization, culture }\end{array}$ & Not represented \\
\hline 7 & $\begin{array}{l}\text { Digital Maturity } \\
\text { Assessment [34] }\end{array}$ & Protiviti Inc. & $\begin{array}{c}\text { Framework: vision mission strategy, } \\
\text { management employees culture, organization } \\
\text { structure process, communication marketing } \\
\text { sales, technology innovation development, big } \\
\text { data analytics automation. }\end{array}$ & Indirect evaluation \\
\hline 8 & $\begin{array}{l}\text { Digital Maturity } \\
\text { Assessment [35] }\end{array}$ & NHS & $\begin{array}{l}\text { Measures how well secondary care providers in } \\
\text { England are making use of digital technology to } \\
\text { achieve a health and care system that is } \\
\text { paper-free at the point of care }\end{array}$ & Indirect evaluation \\
\hline 9 & $\begin{array}{l}\text { Digital Maturity } \\
\text { Assessment Tool } \\
\text { (DMAT) [36] }\end{array}$ & $\begin{array}{l}\text { Digital business } \\
\text { development }\end{array}$ & $\begin{array}{l}\text { Digital maturity is assessed on six dimensions: } \\
\text { Strategy, Culture, Organisation, Processes, } \\
\text { Technology, and finally Customers and Partners }\end{array}$ & Not represented \\
\hline 10 & $\begin{array}{l}\text { Digital Maturity } \\
\text { Assessment [37] }\end{array}$ & Axway & $\begin{array}{l}\text { Digital maturity is assessed on six dimensions: } \\
\text { Vision, Culture, Adoption, Execution, Growth } \\
\text { Digital maturity by area: Attitudes and }\end{array}$ & Not represented \\
\hline 11 & Digital Maturity tool [38] & Digital Leadership Ltd. & $\begin{array}{l}\text { foundations, People, skills and processes, } \\
\text { Systems and information, Outputs } \\
\text { and experiences. }\end{array}$ & Not represented \\
\hline 12 & $\begin{array}{l}\text { Maturity Models for } \\
\text { Hospital Information } \\
\text { Systems [39] }\end{array}$ & $\begin{array}{l}\text { HISMM: Hospital } \\
\text { Information System } \\
\text { Maturity Model }\end{array}$ & Hospital Information Systems & Indirect evaluation \\
\hline 13 & $\begin{array}{l}\text { Maturity Diagnostic } \\
\text { Questionnaire [40] }\end{array}$ & Autodesk & $\begin{array}{l}\text { Design and technological preparation of } \\
\text { production, Production, Management } \\
\text { and logistics }\end{array}$ & Indirect evaluation \\
\hline 14 & $\begin{array}{l}\text { Methodological } \\
\text { Recommendations for } \\
\text { Digital Transformation of } \\
\text { Public Corporations and } \\
\text { Companies with State } \\
\text { Participation [41] }\end{array}$ & $\begin{array}{l}\text { Ministry of } \\
\text { Digital Development, } \\
\text { Communications and } \\
\text { Mass Media of the } \\
\text { Russian Federation }\end{array}$ & $\begin{array}{l}\text { Overall strategic parameters for of public } \\
\text { corporations and companies with } \\
\text { state participation }\end{array}$ & Not represented \\
\hline
\end{tabular}


Table 1. Cont.

\begin{tabular}{|c|c|c|c|c|}
\hline № & Model & Source & Scope & Barrier Evaluation Metrics \\
\hline 15 & $\begin{array}{l}\text { Information Technology } \\
\text { Maturity Evaluation in } \\
\text { Cosmetics Industry [42] }\end{array}$ & $\begin{array}{l}\text { Federal University of } \\
\text { Paraná, Brazil }\end{array}$ & $\begin{array}{c}\text { Scope: people, processes, technology, } \\
\text { business management }\end{array}$ & Not represented \\
\hline 16 & $\begin{array}{l}\text { Business Intelligence } \\
\text { Maturity [43] }\end{array}$ & $\begin{array}{l}\text { Institute of } \\
\text { Information Management }\end{array}$ & Business intelligence (BI) scope & Not represented \\
\hline 17 & $\begin{array}{l}\text { Assessing the Impact } \\
\text { of Digital } \\
\text { Transformation of Health } \\
\text { Services [44] }\end{array}$ & $\begin{array}{l}\text { Expert panel on effective } \\
\text { ways of investing in } \\
\text { Health (EXPH) }\end{array}$ & Health services & Not represented \\
\hline 18 & $\begin{array}{l}\text { Digital Service Units- } \\
\text { Maturity Model [45] }\end{array}$ & Digital HKS & $\begin{array}{c}\text { Political Environment, } \\
\text { Institutional Capacity, } \\
\text { Delivery Capability, } \\
\text { Skills and Hiring, } \\
\text { User-centred Design, } \\
\text { Cross-government Platforms }\end{array}$ & Indirect evaluation \\
\hline
\end{tabular}

The authors' review of the available digital maturity assessment models showed that only five models (of the identified 18) have indirect barrier evaluation metrics. These five models (Digital Maturity Assessment by Protiviti Inc., Digital Maturity Assessment by NHS, Maturity Models for Hospital Information Systems, Maturity diagnostic questionnaire by Autodesk, and Digital Service Units-Maturity Model) allow identifying particular barriers within the scope of the model. However, they do not contain questions aimed directly to identify barriers. The rest of the identified models do not contain tools to reveal and evaluate barriers, making the development of the method for determining barriers in digital transformation a relevant task.

\subsection{Reaserch Objective}

The object of the research is the digital/advanced manufacturing technologies adoption readiness, which can be assessed on both industrial and organisational levels. The authors carried out an expert poll that showed low digital/advanced manufacturing technologies adoption readiness on the industrial level (average readiness of 2.18 across estimated industries). For this reason, the focus subject of the research is the evaluation method for determining barriers of digital transformation on organisational level. The experts' review of the available digital maturity assessment models (see Section 1.3 of the article) showed that only five models (of the identified by the authors 18) have indirect barrier evaluation metrics. The reviewed models do not contain a method to identify barriers to digital transformation.

The article is aimed at developing the method for determining barriers hindering digital transformation. The tasks of the research include:

1. To assess digital/advanced manufacturing technologies adoption readiness (see Section 3.1); obtained results are to be compared to the results of the method for determining barriers approbation in task 2;

2. To develop the method for determining barriers in digital transformation (see Section 3.2).

The authors put forward the hypothesis about the rationality of the authors' method. The method was tested on high-tech machine-building enterprises; the directions for further research were formulated.

The review of the academic literature and available digital maturity assessment models has shown the lack of metrics for barrier evaluation, revealing significant research gap. Therefore, the objective of the research was to develop a method for digital transformation barrier evaluation. The authors put forward the hypothesis about rationality of the authors' method.

The novel method suggested by the authors is approbated in two large industrial companies. The overall barrier equals $39.3 \%$ for a power engineering company, which is a deterrent barrier. The overall barrier equals $75.0 \%$ for a machine-building company, which is a limiting barrier. The results of approbation correspond with results of the expert poll: 
the power engineering company has a lower barrier level, which is in line with the engine building and turbine engineering industry showing higher levels of readiness to adopt digital technologies. The identified limiting barrier for the machine-building company is in line with the lower levels of readiness to adopt digital technologies in other the machinebuilding industries, as derived from the expert poll. These findings support the hypothesis about the rationality of the authors' method.

The paper aims to present the research to academics and practitioners and is divided into the following Section 2: Materials and methods, offering a description of the methods used to perform the digital/advanced manufacturing technologies adoption readiness assessment on industry level and methods for the development of the method for determining barriers in digital transformation; Section 3: Results and Discussion, offering results representation and analysis; Section 4: Conclusions, offering the implications of the research, limitations, and suggestions for further research.

\section{Materials and Methods}

\subsection{Digital/Advanced Manufacturing Technologies Adoption Readiness Assessment}

To measure the level of digital/advanced manufacturing technologies adoption readiness across economic sectors, the expert poll on advanced digital technologies was carried out. [46]. The results regarding digital/advanced manufacturing technologies adoption readiness were processed for the first time for purposes of the present research. A total of 135 experts from both academic and business fields participated in the poll. Three conditions were considered during the sample design:

The first condition was the need to integrate the efforts of the main participants in the digital economy: scientific communities ( $35 \%$ of the sample), business communities ( $62 \%$ of the sample), and governmental structures ( $3 \%$ of the sample).

The second condition was high requirements for the professional competencies of experts: more than half of the participants ( $53 \%$ of the sample) have an academic degree (Ph.D.). A total of 70\% of the respondents belong to representatives of the managerial level of organizations, $14 \%$ are engineering and technical specialists, $9 \%$ are research scientists (non-manager), and $7 \%$ are analytic specialists.

The third condition was the representativeness of various areas of industrial production: the sample includes representatives of more than 12 industries.

The experts were to evaluate the digital/advanced manufacturing technologies adoption readiness across manufacturing industries:

- Automotive;

- Aerospace;

- Engine building;

- Shipbuilding;

- Railway machine building;

- Other vehicles;

- Machine tool building;

- Other machine building;

- Agricultural engineering;

- Other specialized machine building;

- Metallurgical production; and

- Other manufacturing industries.

The poll was designed in the form of a questionnaire. Each expert evaluated each industry on a scale from 1 to 5 , where 1 indicates low readiness and 5 high readiness to adopt digital technologies. The mean value across expert evaluations was calculated to determine the average result for each industry. 


\subsection{Development of the Method for Determining Barriers in Digital Transformation}

The method development for determining barriers in digital transformation was conducted by formulation of the most common key areas within the enterprise, which might comprise digitalisation barriers. For this purpose, an analytical method was used.

- IT infrastructure;

- $\quad$ Existing IT systems;

- Special software requirements;

- Financial resources;

- Qualified specialists and IT personnel;

- Digital manufacturing policy;

- $\quad$ Limited-access information use;

- Regulatory framework; and

- Diverse IT maturity of production cooperation participants.

Manufacturing industry representatives validated the ten formulated areas in manufacturing technologies. These ten areas were translated into 14 questions and presented in a questionnaire that can supplement and add diagnostic value to any available digital maturity assessment model. The number of questions attributed to the area depended on the intended level of accuracy of evaluation achieved by one or more evaluation questions. The authors concluded that such areas as financial resources, qualified specialists and IT personnel, and regulatory framework can constitute various relevant barriers. Therefore, more than one question was formulated for each area.

\section{Results and Discussion}

\subsection{Digital/Advanced Manufacturing Technologies Adoption Readiness Assessment}

Digital/advanced manufacturing technologies adoption readiness assessment (see Figure 1) showed average readiness of 2.18 across estimated industries, which is a low-level readiness. The most advanced and knowledge-intensive industries, such as aerospace, engine building, and turbine engineering, show higher readiness to adopt digital technologies (3.22 and 2.58, respectively). However, all the values received in the expert poll are below the 4.00 mark, which indicates significant barriers the enterprises face in their digital transformation journey.

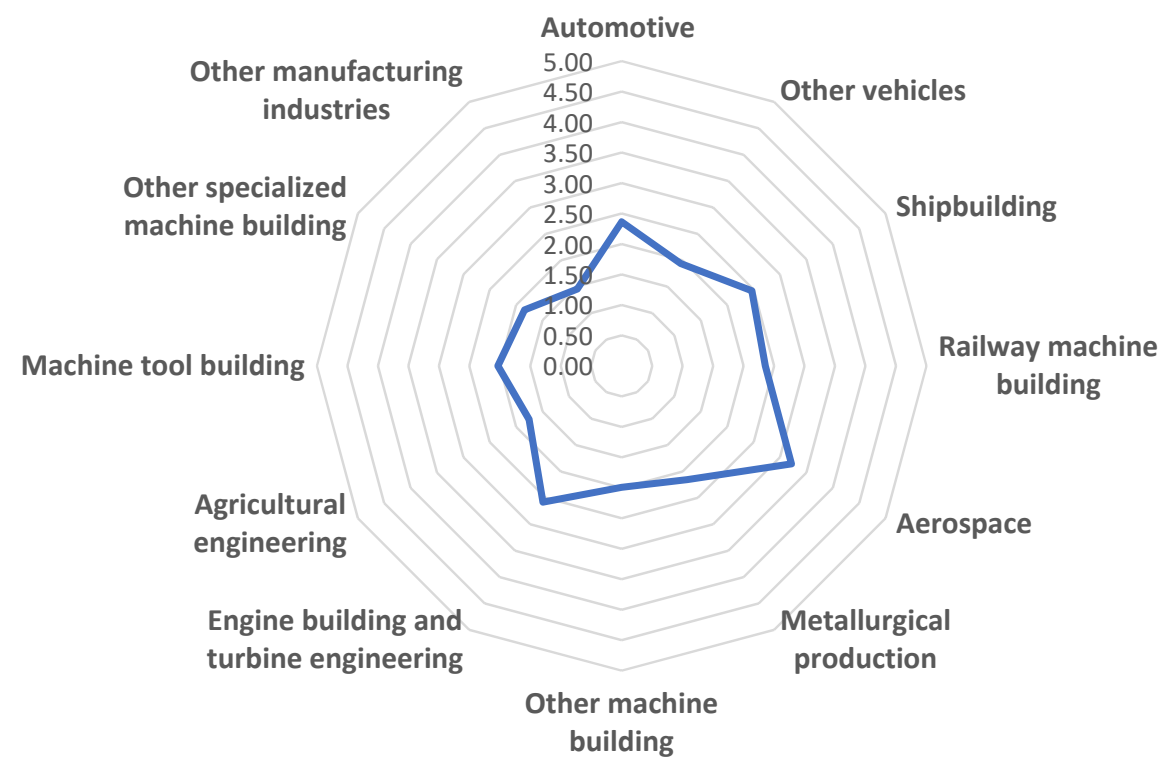

Figure 1. Digital/advanced manufacturing technologies adoption readiness assessment. 


\subsection{Development of the Method for Determining Barriers in Digital Transformation}

A combined quantitative and qualitative approach to assessment is offered: a quantitative evaluation of barrier has a qualitative interpretation for each question (see Table 2). An overall quantitative evaluation can be calculated using Formula (1).

Table 2. The method for determining barriers in digital transformation approbation.

\begin{tabular}{|c|c|c|c|c|}
\hline № & Barrier & $\begin{array}{c}\text { Results in Engine Building } \\
\text { and Turbine Engineering } \\
\text { Sector (Power } \\
\text { Engineering Company) }\end{array}$ & $\begin{array}{l}\text { Results in Other Specialized } \\
\text { Machine-Building (Machine- } \\
\text { Building Company) }\end{array}$ & Interpretation \\
\hline 1 & $\begin{array}{l}\text { Outdated manufacturing } \\
\text { technologies with low } \\
\text { levels of automation }\end{array}$ & 1 & 2 & $\begin{array}{l}\text { There is a barrier (a significant part of production } \\
\text { processes is not automated): } 2 \\
\text { The barrier is of a local nature (processes are automated at } \\
\text { the level of production services and departments): } 1 \\
\text { No barrier (most of the production processes are } \\
\text { automated): } 0\end{array}$ \\
\hline 2 & $\begin{array}{l}\text { Limited capabilities of the } \\
\text { enterprise IT infrastructure }\end{array}$ & 0 & 1 & $\begin{array}{c}\text { There is a barrier (a radical modernization or complete } \\
\text { replacement of the IT infrastructure is required for } \\
\text { digitalisation): } 2 \\
\text { The barrier is local in nature (the IT infrastructure of the } \\
\text { enterprise allows digitalisation of the main processes at } \\
\text { the level of individual services and departments): } 1 \\
\text { No barrier (enterprise IT infrastructure allows for } \\
\text { enterprise-wide digitalisation): } 0\end{array}$ \\
\hline 3 & $\begin{array}{c}\text { The complexity of } \\
\text { integrating digital } \\
\text { technologies with existing } \\
\text { IT systems in the enterprise }\end{array}$ & 1 & 2 & $\begin{array}{l}\text { There is a barrier (a transition to new IT solutions or } \\
\text { software products is required): } 2 \\
\text { The barrier is of a local nature (partial modernization is } \\
\text { required, replacement of subsystems / equipment for } \\
\text { integration with the implemented digital technologies): } 1 \\
\text { There is no barrier (integration of digital technologies is } \\
\text { possible without significant changes to the IT systems of } \\
\text { the enterprise): } 0\end{array}$ \\
\hline 4 & $\begin{array}{l}\text { Availability of special } \\
\text { software requirements }\end{array}$ & 1 & 2 & $\begin{array}{l}\text { There is a barrier (the presence of critical } \\
\text { restrictions/special requirements for software (related to } \\
\text { the terms of licensing agreements/requirements for } \\
\text { ensuring the protection of information constituting a state } \\
\text { secret/selection of developers of IT products (using } \\
\text { imported software products)/requirements for } \\
\text { compatibility within a single information space, etc.)), } \\
\text { hindering the implementation of measures for the } \\
\text { digitalisation of the enterprise: } 2 \\
\text { The barrier is local in nature (the presence of } \\
\text { restrictions/special requirements for software within the } \\
\text { framework of individual services and departments } \\
\text { impede the implementation of measures for the } \\
\text { digitalisation of the enterprise): } 1 \\
\text { There is no barrier (no restrictions/special requirements } \\
\text { for software (related to the terms of licensing } \\
\text { agreements /requirements for ensuring the protection of } \\
\text { information constituting a state secret/selection of } \\
\text { developers of IT products (using imported software } \\
\text { products)/requirements for compatibility within a single } \\
\text { information space, etc.) that hinder the implementation of } \\
\text { measures for the digitalisation of the enterprise): } 0\end{array}$ \\
\hline 5 & $\begin{array}{l}\text { Limited/lack of financial } \\
\text { resources for } \\
\text { enterprise digitalisation }\end{array}$ & 1 & 1 & $\begin{array}{c}\text { There is a barrier (lack of financial resources to carry out } \\
\text { large-scale/complex digitalisation activities): } 2 \\
\text { The barrier is of a local nature (financial resources are } \\
\text { sufficient to carry out activities for the digitalisation of } \\
\text { processes at the level of individual services and } \\
\text { departments): } 1 \\
\text { No barrier (financial resources are sufficient to carry out } \\
\text { enterprise-wide digitalisation activities): } 0\end{array}$ \\
\hline 6 & $\begin{array}{l}\text { Limited/lack of financial } \\
\text { resources to support digital } \\
\text { production technologies }\end{array}$ & 1 & 1 & $\begin{array}{c}\text { There is a barrier (lack of funds to support digital } \\
\text { production technologies): } 2 \\
\text { The barrier is local in nature (financial resources are } \\
\text { sufficient to support digital production technologies at the } \\
\text { level of individual services and departments): } 1 \\
\text { No barrier (financial resources are sufficient to support } \\
\text { enterprise-wide digital manufacturing technologies): } 0\end{array}$ \\
\hline
\end{tabular}


Table 2. Cont.

\begin{tabular}{ccc}
\hline Barrier & $\begin{array}{c}\text { Results in Engine Building } \\
\text { and Turbine Engineering } \\
\text { Sector (Power } \\
\text { Engineering Company) }\end{array}$ & $\begin{array}{c}\text { Results in Other Specialized } \\
\text { Machine-Building (Machine- } \\
\text { Building Company) }\end{array}$ \\
\hline
\end{tabular}

Lack of qualified specialists

7 for the implementation and use of digital

production technologies
Lack/insufficiency of training, retraining, and advanced training

8 programs for the personne

of the enterprise in the current areas of digitalisation of the enterprise
Unreadiness (lack of interest) of the enterprise personnel to implement digital production technologies

There is a barrier (the company does not have specialists with the necessary qualifications for the implementation and use of digital production technologies): 2

The barrier is local in nature (the enterprise is provided with specialists with the necessary qualifications for the implementation and use of digital production
implian technologies at the level of individual services and departments): 1

There is no barrier (the enterprise is provided with specialists with the necessary qualifications for the implementation and use of digital production technologies throughout the enterprise): 0

There is a barrier (the company is not able to carry out training, retraining, and advanced training of personnel in the current areas of digitalisation of the enterprise): 2 The barrier is local in nature (programs for training, retraining, and advanced training of personnel are implemented in certain areas of digitalisation of the enterprise): 1

There is no barrier (programs for training, retraining, and advanced training of personnel are implemented in relevant areas of digitalisation on the basis of the training centre of the enterprise/corporate training centre/with the involvement of consulting firms/under contracts with educational institutions, etc.): 0

There is a barrier (representatives of top management/managers and employees of the main divisions of the enterprise do not show interest in the implementation of digital technologies): 2

The barrier is local in nature (employees of individual services and departments are interested in the implementation of digital production technologies): 1 There is no barrier (representatives

top management and employees of all services and departments are interested in the implementation of digital production technologies): 0

There is a barrier (unavailability of IT departments to implement and support modern digital production technologies throughout the enterprise): 2

Unreadiness of IT

10 departments to implement production technologies

Insufficient elaboration of

the issue of transferring

limited-access

information through

secure-access channels

The barrier is local in nature (IT departments are ready to implement and support modern digital production

technologies in certain areas/services and departments): 1

No barrier (IT departments are mostly ready to

implement and support modern digital manufacturing technologies throughout the enterprise): 0

There is a barrier (the introduction of digital technologies within the framework of individual services and divisions is carried out without taking into account the development strategy of the enterprise in the field of digital production): 2

The barrier is local in nature (decisions on the course of action (strategy) in the field of creating digital production are developed and agreed upon at the level of individual services and departments): 1

There is no barrier (decisions on the course of action (strategy) in the field of creating digital production are developed by the top management of the enterprise together with representatives of various services and departments throughout the enterprise): 0

The barrier is present (the transfer of information of limited access is carried out through "air" channels (on electronic media)): 2

The barrier is of a local nature (there are channels of secure access to information bases in individual services and departments;

the regulations for the transfer of information of limited access within the framework of individual services and divisions were approved): 1

There is no barrier (there are channels of secure access to information bases for all participants of information exchange; regulations for the transfer of information of limited access throughout the enterprise are approved): 0 
Table 2. Cont

\begin{tabular}{|c|c|c|c|c|}
\hline № & Barrier & $\begin{array}{l}\text { Results in Engine Building } \\
\text { and Turbine Engineering } \\
\text { Sector (Power } \\
\text { Engineering Company) }\end{array}$ & $\begin{array}{l}\text { Results in Other Specialized } \\
\text { Machine-Building (Machine- } \\
\text { Building Company) }\end{array}$ & Interpretation \\
\hline 13 & $\begin{array}{l}\text { Insufficient elaboration of } \\
\text { the regulatory framework } \\
\text { in the field of } \\
\text { information interaction }\end{array}$ & 1 & 2 & $\begin{array}{l}\text { There is a barrier (development/updating of regulatory } \\
\text { documents in the field of information interaction at the } \\
\text { enterprise is required): } 2 \\
\text { The barrier is of a local nature (the enterprise has separate } \\
\text { regulatory documents in the field of information } \\
\text { interaction): } 1 \\
\text { There is no barrier (normative documents (standards, } \\
\text { instructions, regulations) in the field of information } \\
\text { interaction at the enterprise scale have been developed): } 0\end{array}$ \\
\hline 14 & $\begin{array}{l}\text { Diverse IT maturity } \\
\text { of production } \\
\text { cooperation participants }\end{array}$ & 1 & 1 & $\begin{array}{l}\text { There is a barrier (the main/key participants in industrial } \\
\text { cooperation cannot carry out information exchange in the } \\
\text { required digital format): } 2 \\
\text { The barrier is local in nature (information exchange in the } \\
\text { required digital format can be carried out by less than half } \\
\text { of the main/key participants in industrial cooperation): } 1 \\
\text { There is no barrier (most of the main/key participants in } \\
\text { industrial cooperation can carry out information } \\
\text { exchange in the required digital format): } 0\end{array}$ \\
\hline
\end{tabular}

The questionnaire consists of 14 questions. The respondents are supposed to assign values: 0,1 , or 2 , following interpretation. The interpretation allows to identify key barriers and to calculate the average barrier using Formula (1).

$$
\begin{gathered}
P=\frac{100}{28} \bullet \sum_{i=1}^{14} a_{i}, \% \\
a_{i} \text {-assessment of the } i \text {-th form indicator. }
\end{gathered}
$$

The average barrier is interpreted:

- Insignificant if the relative generalized barrier is less than $35 \%$;

- Deterrent if the relative generalized barrier is in the range from $35 \%$ to $70 \%$; and

- Limiting if the relative generalized barrier is more than $70 \%$.

A test of the method was conducted with participation of two large industrial companies: a power engineering company and a machine-building company. In both cases, the representatives of the IT division of the company filled in the suggested forms.

The overall barrier equals $39.3 \%$ for a power engineering company, which is a deterrent barrier. The overall barrier equals $75.0 \%$ for a machine-building company, which is a limiting barrier.

The key areas, which constitute barriers for each company, can be derived from the questions with evaluation (2) and (1).

\subsection{Assesment's Results}

Conducted research identified low digital/advanced manufacturing technologies adoption readiness assessment. Since the digital transformation of the manufacturing sector and services and other economic sectors is followed by positive developments in quality of life, it should be a priority to enhance the readiness of the enterprises to adopt digital technologies.

Such enhancement starts with the identification of barriers that hinder digital transformation on the enterprise level. The enterprise level is so crucial to assess because many governmental incentives are aimed at barriers, which exist on regulatory and administrative levels, and help enterprises adopt new technologies by offering grants, consulting services, etc. However, each case of transformation starts with a particular enterprise. Moreover, each enterprise suffers from individual barriers that should be identified and eliminated in order to succeed. The experts' review of the available digital maturity assessment models showed that most of them do not imply barrier-identification tools and metrics.

The novel method suggested by the authors is approbated in two large industrial companies. 
The overall barrier equals $39.3 \%$ for a power engineering company, which is a deterrent barrier. Eleven areas have a local-in-nature barrier.

The overall barrier equals $75.0 \%$ for a machine-building company, which is a limiting barrier. Key problem areas include:

- Outdated manufacturing technologies with low levels of automation.

- The complexity of integrating digital technologies with existing IT systems in the enterprise.

- Availability of special software requirements.

- Lack of qualified specialists for the implementation and use of digital production technologies.

- Lack of a coherent digital manufacturing policy.

- Insufficient elaboration of the issue of transferring limited-access information through secure-access channels.

- Insufficient elaboration of the regulatory framework in the field of information interaction.

The results of approbation correspond with results of the expert poll: the power engineering company has a lower barrier level, which is in line with the engine building and turbine engineering industry showing higher levels of readiness to adopt digital technologies. The identified limiting barrier for the machine-building company is in line with the lower levels of readiness to adopt digital technologies in other machine-building industry derived from the expert poll (see Figure 2).

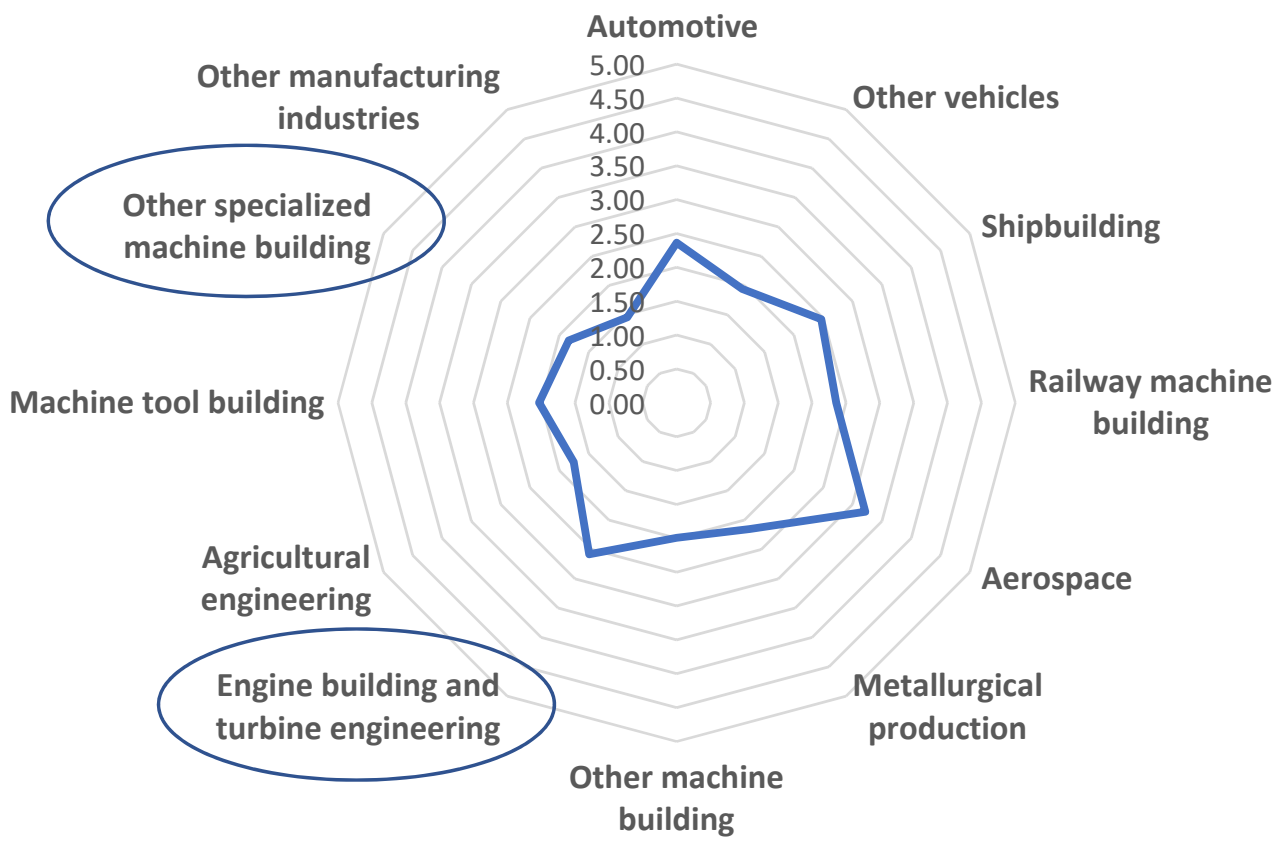

Figure 2. Digital/advanced manufacturing technologies adoption readiness assessment.

These findings support the hypothesis about the rationality of the authors' method. The article's offered method for determining digital transformation barriers can be used in combination with identified digital maturity assessment models. Such combination will strengthen the starting point for digital transformation strategy formulation and implementation and is aimed to enhance digital/advanced manufacturing technologies adoption readiness of enterprises.

The authors recognize the limited approbation scope of the method.

\section{Conclusions}

The article is aimed at developing the method for determining barriers hindering digital transformation. The authors put forward a hypothesis about rationality of the authors' method. The method is tested on high-tech machine-building enterprises; the directions for further research are formulated.

Scientific results obtained and discussed in the article include: 
1. Digital/advanced manufacturing technologies adoption readiness assessment results showed low digital/advanced manufacturing technologies adoption readiness (average readiness of 2.18 across estimated industries).

2. The method for determining barriers in digital transformation was developed and approbated in two large industrial companies. The overall barrier equals $39.3 \%$ for a power engineering company, which is a deterrent barrier. The overall barrier equals $75.0 \%$ for a machine-building company, which is a limiting barrier.

The results are relevant for both academics studying new technologies adoption and practitioners in manufacturing industries. In the academic field, the research gap concerning barrier assessment has been identified and articulated. Theoretical results can be used to further build on and propose more elaborate or industry-specific methods for digital maturity assessment and barrier evaluation. The developed method can be used to gather more empirical data from various industries to study in detail the level of barriers.

Practitioners are offered a ready-to-use barrier-evaluation method. For the most complete assessment, the method can be supplemented with digital maturity assessment models proposed by PWC (1 Embankment Pl, London WC2N 6RH, UK), Avanade (1191 Second Avenue, Suite 100 Seattle, WA 98101, USA), BCG (200 Pier 4 Blvd Boston, MA 02210, United States), Deloitte (30 Rockefeller Plaza, New York, NY 10112-0015, United States), Protiviti Inc. (1290 Avenue of the Americas New York, NY 10104, United States), etc., and, when combined, can be the starting point of digital transformation strategy formulation for manufacturing enterprises.

Limitations of the research include narrowing the focus to manufacturing industries and the limited approbation scope of the method. Further research can be focused on gathering more data through suggested questionnaires in combination with any available digital maturity assessment model to rest and revise the method. Another important direction is a theoretical basis for decision-making and strategy formulation steps concerning identified barriers.

Author Contributions: A.B.: Research problem formulation; research goal formulation; academic supervision; funding acquisition; writing - review. O.R.: digital/advanced manufacturing technologies adoption readiness assessment conceptualization—data acquisition; the method for determining barriers in digital transformation, supervision, and project administration. E.P.: digital/advanced manufacturing technologies adoption readiness assessment-data processing and interpretation; formal analysis of the available digital maturity assessment models interpretation; writing —original draft preparation; visualization. A.G.: the method for determining barriers in digital transformation approbation-data processing and interpretation; writing-review and editing. K.S.: the method for determining barriers in digital transformation approbation-data processing and interpretation; writing-review and editing. All authors have read and agreed to the published version of the manuscript.

Funding: The research is partially funded by the Ministry of Science and Higher Education of the Russian Federation as part of World-class Research Centre program: Advanced Digital Technologies (contract No. 075-15-2020-934 dated 17 November 2020).

Conflicts of Interest: The authors declare no conflict of interest.

\section{References}

1. Ciani Scarnicci, M.; Laino, A.; Belcaro, M.; Vita, C. Economic Growth, Quality of Life, Life Styles and Sustainability: Correlations and New Variables to Be Considered as Indicators in Recent Literature. In Italian Studies on Quality of Life; Springer: Cham, Switzerland, 2019; pp. 309-319, ISBN 978-3-658-26418-5.

2. Shumilina, V.; Lermontova, A. Level and quality of life in the context of the world economy. In Directions for Improving the Economic Security of the Russian Federation in the Context of Economic Recession and Pandemic; AUS PUBLISHERS: Ultimo, Australia, 2021; pp. 106-113, ISBN 978-0-645-10240-6.

3. Савичев, К.Д.; Глухов, В.В. Влияние энергоемкостиВВП на качество жизни: показателиоценки и методы государственной поддержки. Научно-ТехническиеВедомостиСанкт-Петербургского Государственного Политехнического Университета. Экономические Науки 2018, 11. [CrossRef]

4. Mytareva, L.; Gorshkova, N.; Shkarupa, E.; Yalmaev, R. The Cyber Economy and Digitization: Impacts on the Quality of Life. In The Cyber Economy; Springer: Cham, Switzerland, 2019; pp. 19-30, ISBN 978-3-030-31565-8. 
5. Katz, R.L.; Koutroumpis, P. Measuring digitization: A growth and welfare multiplier. Technovation 2013, 33, 314-319. [CrossRef]

6. Razumovsky, V.; Sultanova, A.; Chechina, O.; Nikonorova, S. The Impact of the Digital Economy on the Quality of Life. In Institute of Scientific Communications Conference; Springer: Cham, Switzerland, 2020; pp. 417-423, ISBN 978-3-030-29585-1.

7. Vaganova, O.V.; Solovjeva, N.E.; Lesovik, R.V.; Leonidovna, L.S. Digital Transformation of Russia's Agricultural Sector. Utop. Lat. Am. Prax. 2020, 12, 397-406.

8. Litvintseva, G.; Karelin, I. Effects of digital transformation of the economy and quality of life in Russia. Terra Econ. 2020, $18,53-71$. [CrossRef]

9. Dmitrieva, E. Assessment of the Level of Digitalization of the Economy and Society in Russia. In Proceedings of the Russian Conference on Digital Economy and Knowledge Management (RuDEcK 2020), Voronezh, Russia, 27-29 February 2020.

10. Gartner Top Strategic Technology Trends for 2021. Available online: https://www.gartner.com/smarterwithgartner/gartner-topstrategic-technology-trends-for-2021/ (accessed on 4 June 2021).

11. The Impact of Digitalization on Strategy. Available online: https://www.mbdconsulting.ch/publications/digitalizationcorporate-strategy (accessed on 4 June 2021).

12. Teece, D.J. Business Models, Business Strategy and Innovation. Long Range Plan. 2010, 43, 172-194. [CrossRef]

13. Боровков, А.И.; Рябов, Ю.А.; Марусева, В.М. Новая парадигма цифрового проектирования и моделирования глобально конкурентоспособной продукции нового поколения. In Цифровое производство: методы, экосистемы, технологии; МШУСколково: Moscow, Russia, 2017; pp. 28-31.

14. OECD. Measuring the Digital Transformation a Roadmap for the Future; OECD: Paris, France, 2019.

15. Verhoef, P.C.; Broekhuizen, T.; Bart, Y.; Bhattacharya, A.; Qi Dong, J.; Fabian, N.; Haenlein, M. Digital transformation: A multidisciplinary reflection and research agenda. J. Bus. Res. 2021, 122, 889-901. [CrossRef]

16. Li, H.; Yang, C. Digital Transformation of Manufacturing Enterprises. Procedia Comput. Sci. 2021, 187, 24-29. [CrossRef]

17. Sklyar, A.; Kowalkowski, C.; Tronvoll, B.; Sörhammar, D. Organizing for digital servitization: A service ecosystem perspective. J. Bus. Res. 2019, 104, 450-460. [CrossRef]

18. Li, L.; Su, F.; Zhang, W.; Mao, J.-Y. Digital transformation by SME entrepreneurs: A capability perspective. Inform. Syst. J. 2018, 28, 1129-1157. [CrossRef]

19. Cugno, M.; Castagnoli, R.; Büchi, G. Openness to Industry 4.0 and performance: The impact of barriers and incentives. Technol. Forecast. Soc. Chang. 2021, 168, 120756. [CrossRef]

20. Chauhan, C.; Singh, A.; Luthra, S. Barriers to industry 4.0 adoption and its performance implications: An empirical investigation of emerging economy. J. Clean. Prod. 2021, 285, 124809. [CrossRef]

21. Vogelsang, K.; Liere-Netheler, K.; Packmohr, S.; Hoppe, U. Barriers to Digital Transformation in Manufacturing: Development of a Research Agenda. In Proceedings of the Hawaii International Conference on System Sciences 2019, Grand Wailea, HI, USA, 1-8 January 2019.

22. Neto, A.A.; Deschamps, F.; da Silva, E.R.; de Lima, E.P. Digital twins in manufacturing: An assessment of drivers, enablers and barriers to implementation. Procedia CIRP 2020, 93, 210-215. [CrossRef]

23. Ramilo, R.; Embi, M.R.B. Critical analysis of key determinants and barriers to digital innovation adoption among architectural organizations. Front. Archit. Res. 2014, 3, 431-451. [CrossRef]

24. Jones, M.D.; Hutcheson, S.; Camba, J.D. Past, present, and future barriers to digital transformation in manufacturing: A review. J. Manuf. Syst. 2021, 60, 936-948. [CrossRef]

25. Volberda, H.W.; Khanagha, S.; Baden-Fuller, C.; Mihalache, O.R.; Birkinshaw, J. Strategizing in a digital world: Overcoming cognitive barriers, reconfiguring routines and introducing new organizational forms. Long Range Plan. 2021, 102110, in press. [CrossRef]

26. Becker, J.; Niehaves, B.; Poeppelbuss, J.; Simons, A. Maturity Models in IS Research. In Proceedings of the ECIS 2010 Proceedings, Pretoria, South Africa, 7-9 June 2010.

27. How to Measure Digitalization? A Critical Evaluation of Digital Maturity Models ISpringerLink. Available online: https: / /link.springer.com/chapter/10.1007/978-3-030-44999-5_30 (accessed on 4 June 2021).

28. Industry 4.0-Self Assessment. Available online: https://i40-self-assessment.pwc.de/i40/landing/ (accessed on 4 June 2021).

29. Digital Maturity Model. InfoCert. Available online: https://infocert.digital/digital-maturity-model/ (accessed on 4 June 2021).

30. Digital Maturity Assessment I Avanade. Available online: https://www.avanade.com/en/thinking/rethink/digital-maturityassessment (accessed on 4 June 2021).

31. Digital Maturity. Available online: https://www.bcg.com/capabilities/digital-technology-data/digital-maturity (accessed on 4 June 2021).

32. Government of South Australia. Digital Maturity Assessment Tool—Governance and Leadership. Available online: https:// www.dpc.sa.gov.au/responsibilities/ict-digital-cyber-security/toolkits/digital-transformation-toolkit (accessed on 4 June 2021).

33. Deloitte. Digital Maturity Model Achieving Digital Maturity to Drive Growth. 2018. Available online: https://www2.deloitte. $\mathrm{com} / \mathrm{be} / \mathrm{en} / \mathrm{pages}$ /strategy-operations/strategy-analytics-mergers-acquisitions/articles/so-deloitte-digital-maturity-survey. html (accessed on 4 June 2021).

34. Protiviti | Digital Transformation Assessment I Resilience \& Performance in a Digital World. Available online: http:/ /landing protiviti.com/digital (accessed on 4 June 2021). 
35. NHS England Digital Maturity Assessment. Available online: https:/ /www.england.nhs.uk/digitaltechnology/connecteddigitalsystems/ maturity-index/ (accessed on 4 June 2021).

36. Digital Maturity Assessment Tool (DMAT)—Digital Business Development. Available online: https://dbd.au.dk/dmat/ (accessed on 4 June 2021).

37. Digital Maturity Assessment 1. Available online: https:/ /www.axway.com/en/maturity-assessment (accessed on 4 June 2021).

38. Digital Maturity | An Invaluable Tool to Measure and Improve the Digital Maturity of Your Organisation. Available online: https: / / digitalmaturity.org/ (accessed on 4 June 2021).

39. Carvalho, J.; Rocha, Á.; Braga de Vasconcelos, J. Maturity Models for Hospital Information Systems Management: Are They Mature? In Innovation in Medicine and Healthcare; Springer: Cham, Switzerland, 2015; Volume 45, pp. 541-552, ISBN 978-3-319-23023-8.

40. Руководство по цифровой трансформации производственных предприятий | Поиск | Autodesk Knowledge Network. Available online: https:/ / knowledge.autodesk.com/ru/search-result/caas/simplecontent/content/-D1-80-D1-83-D0-BA-D0-BED0-B2-D0-BE-D0-B4-D1-81-D1-82-D0-B2-D0-BE--D0-BF-D0-BE--D1-86-D0-B8.html (accessed on 4 June 2021).

41. Методические рекомендации по цифровой трансформации государственных корпораций и компаний с государственным участием. Available online: / ru/documents/7342/ (accessed on 4 June 2021).

42. Pedrini, C.; Frederico, G. Information Technology Maturity Evaluation in a Large Brazilian Cosmetics Industry. Int. J. Bus. Admin. 2018, 9, 15. [CrossRef]

43. Lahrmann, G.; Marx, F.; Winter, R.; Wortmann, F. Business Intelligence Maturity: Development and Evaluation of a Theoretical Model. In Proceedings of the 2011 44th Hawaii International Conference on System Sciences, Kauai, HI, USA, 4-7 January 2011; pp. 1-10.

44. EXPH; Barry, M. EXPH Assessing the Impact of Digital Transformation of Health Services; Publications Office of the European Union: Luxembourg, 2018.

45. Eaves, D. Digital Maturity Self Assessment Exercise. Available online: https://medium.com/digitalhks/digital-maturity-selfassessment-exercise-735647b2ba23 (accessed on 4 June 2021).

46. Roadmap for the Development of Cross-Cutting Digital Technology “New Manufacturing Technologies": Findings and Prospects. Available online: https://maginnov.ru/en/magazine/archive/2019/innovations-n11-2019/roadmap-for-the-developmentof-cross-cutting-digital-technology-new-manufacturing-technologies-findings-and-prospects (accessed on 8 June 2021). 